\title{
ANALISIS PERTUMBUHAN EKONOMI INKLUSIF DI INDONESIA
}

\author{
YUNIAR SRI HARTATI \\ Dosen Prodi Ekonomi Pembangunan, Sekolah Tinggi Ilmu Ekonomi Port Numbay
}

\begin{abstract}
This research was conducted because of changes in economic growth that occur due to many supporting factors. Economic growth will continue to increase if it is supported by economic development. However, economic growth in Indonesia during 2010-2019 has not shown results that continue to increase at the national level in addition to poverty and inequality that have not been able to decrease. This condition is contrary to the goal of achieving inclusive economic growth. This study aims to measure and analyze Inclusive Economic Growth and the factors that influence it. There are two analytical methods used in this study, namely the analysis of the Poverty-Equivalent Growth Rate (PEGR) model and multiple linear regression analysis with time series data. The results of the study show that in the last decade inclusive economic growth in Indonesia has not been consistently achieved every year. The results of the time series data regression analysis show that the variables of government spending on education and government spending on health have a significant effect on inclusive economic growth. The variable of government expenditure on education has an inversely proportional effect on inclusive economic growth, while the open unemployment rate (TPT) variable has no significant effect on inclusive economic growth. The efforts that can be made through the implications of government policies are strengthening the Smart Indonesia Program (PIP), to vocational education, strengthening health programs through the addition of health facilities, recruiting medical personnel, to maximizing the healthy Indonesia card and BPJS.
\end{abstract}

Keywords: Government Expenditure, TPT, Inclusive Economic Growth.

Abstrak: Penelitian ini dilakukan karena adanya perubahan pertumbuhan ekonomi yang terjadi karena banyaknya factor pendukung.Pertumbuhan ekonomi akan terus meningkat jika didukung dengan pembangunan ekonomi. Namun pertumbuhan ekonomi di Indonesia selama tahun 2010-2019 belum menunjukkan hasil yang terus meningkat pada level nasional disamping itu kemiskinan dan ketimpangan yang belum dapat menurun. Kondisi tersebut bertolakbelakang dengan tujuan tercapainya pertumbuhan ekonomi inklusif. Penelitian ini bertujuan untuk mengukur dan menganalisis Pertumbuhan Ekonomi Inklusif dan faktor-faktor yang mempengaruhinya. Terdapat dua metode analisis yang digunakan dalam penelitian ini, yaitu analisis model Poverty-Equivalent Growth Rate (PEGR) dan analisis regresi linier berganda dengan data time series. Hasil penelitian menunjukan bahwa pada satu dekade terakhir pertumbuhan ekonomi inklusif di Indonesia belum konsisten tercapai setiap tahun. Hasil analisis regresi data time series menunjukkan bahwa variabel pengeluaran pemerintah bidang pendidikan dan pengeluaran pemerintah bidang kesehatan berpengaruh signifikan terhadap pertumbuhan ekonomi inklusif. Variabel pengeluaran pemerintah bidang pendidikan memiliki pengaruh yang berbanding terbalik terhadap pertumbuhan ekonomi inklusif, Sedangkan variabel tingkat pengangguran terbuka (TPT) berpengaruh tidak signifikan tehadap pertumbuhan ekonomi inklusif. Adapun upaya yang dapat dilakukan melalui impikasi kebijakan pemerintah yaitu penguatan Program Indonesia Pintar (PIP), hingga pendidikan vokasi, penguatan program kesehatan melalui penambahan fasilitas kesehatan, perekrutan tenaga medis, hingga memaksimalkan kartu Indonesia sehat dan BPJS.

Kata Kunci : Pengeluaran Pemerintah, TPT, Pertumbuhan Ekonomi Inklusif.

\section{Pendahuluan}

Berbicara mengenai pertumbuhan ekonomi, dimana pertumbuhan ekonomi sendiri dimaknai sebagai peningkatan nilai serta jumlah produksi barang dan layanan jasa yang biasanya dihitung oleh suatu negara dalam kurun waktu tertentu. Ekonomi suatu negara dapat dikatakan bertumbuh ketika kegiatan ekonomi masyarakatnya berdampak langsung pada kenaikan produksi barang dan jasa. Aktivitas ini juga turut menjadi faktor naiknya pendapatan nasional.

Pertumbuhan ekonomi merupakan masalah perekonomian jangka panjang, dan pertumbuhan ekonomi merupakan fenomena penting yang dialami dunia belakangan ini. Proses pertumbuhan ekonomi tersebut dinamakan sebagai Modern Economic Growth. Pada
On Assets.

dasarnya, pertumbuhan ekonomi diartikan sebagai suatu proses pertumbuhan output perkapita dalam jangka panjang. Hal ini berarti dalam jangka panjang, kesejahteraan tercermin pada peningkatan output perkapita yang sekaligus memberikan banyak alternatif dalam mengkonsumsi barang dan jasa, serta diikuti oleh daya beli masyarakat yang semakin meningkat.

Pertumbuhan ekonomi juga bersangkut paut dengan proses peningkatan produksi barang dan jasa dalam kegiatan ekonomi masyarakat. Dapat dikatakan, bahwa pertumbuhan menyangkut perkembangan yang berdimensi tunggal dan diukur engan meningkatnya hasil produksi dan pendapatan. Dalam hal ini berarti terdapatnya kenaikan dalam pendapatan nasional yang ditunjukkan oleh besarnya 
nilai Produk Domestik Bruto (PDB). Indonesia, sebagai suatu negara yang sedang berkembang sedang giat melaksanakan pembangunan secara berencana dan bertahap, tanpa mengabaikan usaha pemerataan dan kestabilan.

Pembangunan nasional mengusahakan tercapainya pertumbuhan ekonomi yang cukup tinggi, yang pada akhirnya memungkinkan terwujudnya peningkatan taraf hidup dan kesejahteraan seluruh rakyat. Pertumbuhan ekonomi Indonesia dari tahun 2004-2014 terus mengalami fluktuasi. Fluktuasi PDB tertinggi Indonesia terjadi pada tahun 2014 sebesar 7,98\% dan yang paling rendah pada tahun 2009 sebesar 4,54\%. Rendahnya pertumbuhan ekonomi pada tahun 2009 disebabkan kondisi perekonomian global yang masih mengalami tekanan akibat krisis menghadapkan perekonomian Indonesia pada beberapa tantangan yang tidak ringan pada tahun 2009 . Tantangan tersebut cukup berat terutama pada awal tahun 2009, akibat masih kuatnya dampak krisis perekonomian global yang mencapai puncaknya pada triwulan terakhir tahun 2008.

Ketidakpastian yang terkait dengan sampai seberapa dalam kontraksi global dan sampai seberapa cepat pemulihan ekonomi global akan terjadi, bukan saja menyebabkan tingginya risiko di sektor keuangan, tetapi juga berdampak negatif pada kegiatan ekonomi di sektor riil domestik. Kondisi ini mengakibatkan stabilitas moneter dan sistem keuangan pada triwulan pertama 2009 masih mengalami tekanan berat, sementara pertumbuhan ekonomi masih dalam tren menurun akibat kontraksi ekspor barang dan jasa yang cukup dalam.

Menurut Michael Todaro $(2000,44)$, pertumbuhan ekonomi adalahkenaikan kapasitas jangka panjang dari negara yang bersangkutan untukmenyediakan berbagai barang ekonomi kepada penduduknya. Kenaikankapasitas tersebut dimungkinkan oleh adanya kamajuan atau penyesuaian-penyesuaian teknologi, intitusional dan ideologi terhadap berbagai keadaanyang ada.

Perkembangan ekonomi mengandung arti yang lebih luas sertamencakup perubahan pada susunan ekonomi masyarakat secaramenyeluruh. Pembangunan ekonomi pada umunya didefinisikan sebagaisuatu proses yang menyebabkan kenaikan pendapatan riil perkapitapenduduk suatu negara dalam jangka panjang yang disertai oleh perbaikansistem kelembagaan.

Pertumbuhan ekonomi Indonesia menunjukkan perkembangan yang berfluktuatif. Perkembangan pertumbuhan ekonomi tersebut dapat disebabkan oleh beberapa faktor baik dari faktor ekonomi maupun non ekonomi. Faktor ekonomi dapat berupa kebijakan pemerintah seperti kebijakan fiskal dan kebijakan moneter, kondisi ekonomi negara lain, dan faktor non ekonomi seperti bencana alam, sosial budaya, dan lain-lain. Terdapat beberapa permasalahan ekonomi yang terjadi di negara ini. Salah satu nya yang utama yaitu tingkat kemiskinan. Tingkat kemiskinan di Indonesia masih menunjukkan angka yang cukup tinggi.

Pertumbuhan ekonomi Indonesia selama 10 tahun terakhir (2010 -2019) mengalami penurunan, dapat dilihat pada gambar 1. Berbeda dengan tingkat kemiskinan di Indonesia selama 10 tahun terakhir (2010 -2019) yang berfluktualif, dapat dilihhat pada gambar 2 .

\section{Gambar 1. \\ Pertumbuhan Ekonomi di Indonesia \\ Tahun 2010 - 2019}

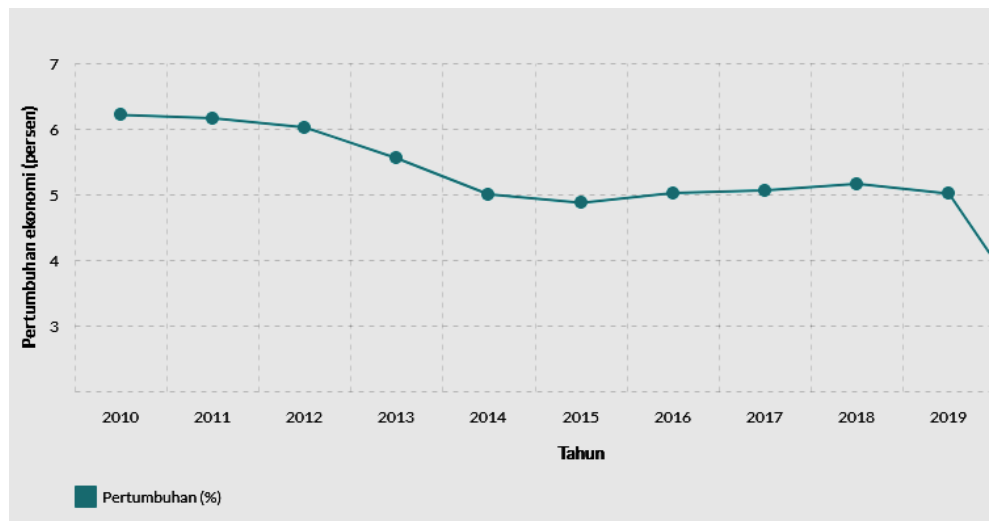

Sumber: BPS, 2020 
Gambar 2.

Tingkat Kemiskinan di Indonesia

Tahun 2010 - 2019

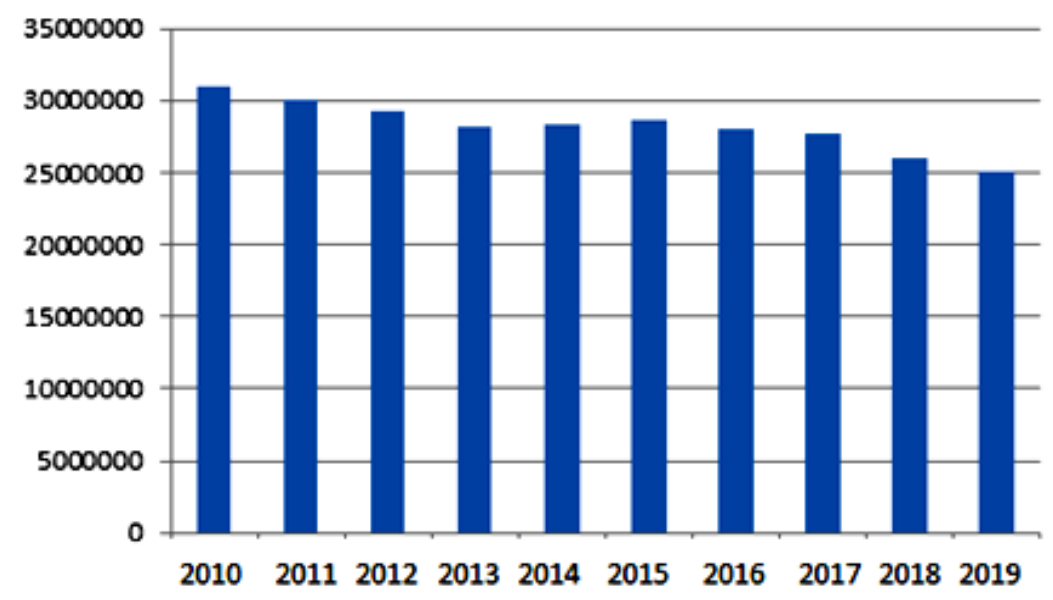

Sumber: BPS, 2020

Untuk itu Pemerintah akan selalu melaksanakan Pembangunan ekonomi yang dapat menciptakan akses dan kesempatan yang luas bagi seluruh lapisan masyarakat secara berkeadilan, meningkatkan kesejahteraan, serta mengurangi kesenjangan antar kelompok dan wilayah (ekonomi inklusif) merupakan tujuan penting yang saat ini sedang dilakukan oleh pemerintah. Untuk menunjang pelaksaannya pemerintah mengeluarkan beberapa kebijakan yang dapat meningkatkan pertumbuhan ekonomi inklusif. Salah satu hasil/output dari kebijakan pemerintah tersebut adalah menghasilkan sumber daya manusia yang dapat memiliki pendidikan yang baik dan kesehatan yang prima.

Kebijakan pemerintah ini dapat mempengaruhi peningkatan pertumbuhan ekonomi dan kualitas sumberdaya manusia serta menurunkan permasalahan pembangunan yang terjadi. Salah satu kebijakan di Indonesia adalah kebijakan fiskal, yang dapat mendukung peningkatan sumberdaya manusia khususnya pengeluaran pemerintah melalui pengeluaran di bidang pendidikan dan pengeluaran pemerintah dibidang kesehatan, untuk mengurangi kemiskinan dan ketimpangan sehingga mengarah kepada pemerataan pembangunan. Selain dari pembangunan pada kualitas sumber daya manusia itu sendiri, adanya jumlah tenaga kerja yang produktif juga merupakan hal penting dalam mendukung pembangunan, karena apabila terjadi peningkatan tenaga kerja produktif maka output perekonomian juga dapat meningkat, namun hal tersebut juga harus diimbangi dengan adanya suatu sarana atau prasarana yang mendukung, baik berupa kebijakan ataupun yang lainnya. Sehingga peningkatan tenaga kerja yang produktif atau biasa tergolong dalam angkatan kerja dapat terserap dalam lapangan kerja yang tinggi pula dan dapat meningkatkan pertumbuhan ekonomi dalam mencapai inklusifitas.

Tingkat pendidikan di Indonesia masih mencerminkan belum maksimal dalam mendorong pertumbuhan ekonomi inklusif melalui pengeluaran pemerintah bidang pendidikan. Hal tersebut juga dapat disebabkan bahwa jasa atau akses pendidikan yang memadai belum banyak dirasakan oleh masyarakat dengan kondisi ekonomi menengah ke bawah, sehingga pada saat tertentu memperburuk distribusi pendapatan, sehingga hal tersebut bertolak belakang dengan konsep pertumbuhan ekonomi yang inklusif.

Pertumbuhan ekonomi yang ekspansif diharapkan menjadi pendorong pembangunan inklusif yaitu pembangunan ekonomi yang mampu menciptakan lapangan pekerjaan, mengurangi kemiskinan dan kesenjangan. Harapannya bahwa Indonesia dan negaranegara lain harus menjalankan 'Pembangunan Inklusif' agar dunia berhasil dalam mengurangi kemiskinan dan ketidakadilan global. Beliau juga menyebutkan bahwa pembangunan inklusif adalah pembangunan yang berkualitas, yaitu pembangunan yang memperhitungkan pertumbuhan (pro-growth), penyerapan tenaga kerja (projob), mengurangi kemiskinan (pro-poor) dan memperhatikan lingkungan (pro-environment).

\section{Tujuan Penelitian}

Penelitian ini bertujuan untuk mengukur dan menganalisis Pertumbuhan Ekonomi Inklusif dan faktorfaktor yang mempengaruhinya. 


\section{Pembatasan Masalah}

Dalam penelitian ini menggunakan variabel dependen (terikat) yaitu Pertumbuhan Ekonomi Inklusif Indoensia tahun 2010-2019, sedangkan untuk variabel independent (bebas) menggunakan data Pengeluaran Pemerintah Bidang Pendidikan Indonesia tahun 2010-2019, Pengeluaran Pemerintah Bidang Kesehatan Indonesia tahun 2010-2019 dan Tingkat Pengganguran Terbuka (TPT) Indonesia tahun 2010-2019.

\section{Landasan Teori \\ Pertumbuhan Ekonomi}

Pertumbuhan ekonomi seringkali dikaitkan dengan kemajuan atau pencapaian suatu Negara dalam kurun waktu tertentu, akan tetapi itu merupakan bahasa awalnya. Pengertian pertumbuhan ekonomi adalah kondisi perekonomian suatu Negara untuk menuju yang lebih baik secara berkelanjuatan/berkesinambungan dalam kurung waktu tertentu.'Pertumbuhan ekonomi adalah proses kenaikan output perkapita dalam jangka panjang (Boediono, 1999:8). Pengertian tersebut mencakup tiga aspek yaitu : proses, output perkapita dan jangka panjang. Pertumbuhan ekonomi merupakan suatu proses bukan gambaran ekonomi pada suatu saat.

Pertumbuhan ekonomi adalah proses kenaikan output perkapitadalam jangka panjang. Tekanannya pada tiga aspek, yaitu: proses, outputperkapita dan jangka panjang. Pertumbuhan ekonomi adalah suatu proses, bukan suatu gambaran ekonomi pada suatu saat. Disini kita melihat aspekdinamis dari suatu perekonomian, yaitu bagaimana suatu perekonomianberkembang atau berubah dari waktu ke waktu. Tekanannya ada padaperubahan atau perkembangan itu sendiri.

Menurut Prof. Simon Kuznets, pertumbuhan ekonomi adalahkenaikan kapasitas jangka panjang dari negara yang bersangkutan untukmenyediakan berbagai barang ekonomi kepada penduduknya. Kenaikankapasitas tersebut dimungkinkan oleh adanya kamajuan atau penyesuaianpenyesuaian teknologi, intitusional dan ideologiterhadap berbagai keadaanyang ada.

Perkembangan ekonomi mengandung arti yang lebih luas sertamencakup perubahan pada susunan ekonomi masyarakat secaramenyeluruh. Pembangunan ekonomi pada umunya didefinisikan sebagaisuatu proses yang menyebabkan kenaikan pendapatan riil perkapitapenduduk suatu negara dalam jangka panjang yang disertai oleh perbaikansistem kelembagaan.

Pembangunan ekonomi merupakan suatu proses yang berartiperubahan yang terjadi terus menerus, usaha untuk menaikkan pendapatanperkapita, kenaikan pendapatan perkapita harus terus berlangsung dalamjangka panjang dan yang terakhir perbaikan sistem kelembagaan disegalabidang (misalnya ekonomi, politik, hukum, sosial, dan budaya). Sistem inibisa ditinjau dari dua aspek yaitu: aspek perbaikan dibidang organisasi(institusi) dan perbaikan dibidang regulasi baik legal formal maupuninformal.5 Dalam hal Ini, berarti pembangunan ekonomi merupakan suatuusaha tindakan aktif yang harus dilakukan oleh suatu negara dalam rangkameningkatkan pendapatan perkapita. Dengan demikian, sangat dibutuhkanperan serta masyarakat, pemeritah, dan semua elemen yang terdapat dalamsuatu negara untuk berpartisipasi aktif dalam proses pembangunan.

Dari berbagai teori pertumbuhan yang ada yakni teori HaroldDomar, Neoklasik, dari Solow, dan teori endogen oleh Romer, bahwasanyaterdapat tiga faktor atau komponen utama dalam pertumbuhan ekonomi.Ketiganya adalah:a) Akumulasi modal, yang meliputi semua bentuk atau jenis investasi baruyang ditanamkan pada tanah, peralatan fisik, dan modal atau sumberdaya manusia.b) Pertumbuhan penduduk, yang beberapa tahun selajutnya akanmemperbanyak jumlah angkatan kerja.c) Kemajuan teknologiPembangunan daerah dilaksanakan untuk mencapai tiga tujuanpenting, yaitu mencapai pertumbuhan (growth), pemerataan (equity), dankeberlanjutan (sustainability). Pertumbuhan (growth), tujuan yang pertama adalah pertumbuhanditentukan sampai dimana kelangkaan sumber daya dapat terjadi atlassumber daya manusia, peralatan, dan sumber daya alam dapatdialokasikan secara maksimal dan dimanfaatkan untuk meningkatkankegiatan produktif.

Pemerataan (equity), dalam hal ini mempunyai implikasi dalampencapaian ada tujuan yang ketiga, sumber daya dapat berkelanjutanmaka tidak boleh terfokus hanya pada satu daerah saja sehingga manfaatyang diperoleh dari pertumbuhan dapat dinikmati semua pihak denganadanya pemerataan.Berkelanjutan (sustainability), sedangkan tujuan berkelanjutan,pembangunan daerah harus memenuhi syarat-syarat bahwa penggunaansumber daya baik yang ditransaksikan melalui sistem pasar maupundiluar sistem pasar harus tidak melampaui kapasitas kemampuanproduksi.

Pembangunan daerah dan pembangunan sektoral perlu selalu dilaksanakan dengan selaras, sehingga pembangunan sektoral yangberlangsung didaerah-daerah, benar-benar dengan potensi dan prioritasdaerah. Untuk keseluruhan pembangunan, daerah juga benarbenarmerupakan satu kesatuan politik, ekonomi, sosial, budaya dan pertahanankeamanan didalam mewujudkan tujuan nasional. 


\section{Pertumbuhan Ekonomi Inklusif}

Indonesia, melalui Bappenas, kemudian mendefinisikan pembangunan ekonomi inklusif sebagai pertumbuhan ekonomi yang menciptakan akses dan kesempatan yang luas bagi seluruh lapisan masyarakat secara berkeadilan, meningkatkan kesejahteraan, dan mengurangi kesenjangan antar kelompok dan wilayah. Untuk itu pula, pemerintah Indonesia melalui Bappenas telah mengeluarkan Indeks Pembangunan Ekonomi Inklusif Tingkat Nasional Tahun 2011-2017 yang dapat dimanfaatkan untuk merumuskan kebijakan pembangunan yang fokus untuk mendorong pembangunan yang lebih inklusif.

Indonesia sendiri sebenarnya sudah memikirkan bahwa paradigma pertumbuhan ekonomi di masa depan tidak hanya difokuskan pada pertumbuhan ekonomi saja, tetapi harus memperhatikan pembangunan yang inklusif. Pendekatan pembangunan yang terlalu berorientasi kepada pertumbuhan, telah menghasilkan eksklusi sosial dan tiga krisis besar, berupa: ketimpangan sosial, kemiskinan dan kerusakan lingkungan, sehingga perlu paradigma pembangunan baru yang lebih bersifat inklusif.

Pembangunan dan pertumbuhan ekonomi harus dapat memberikan kontribusi yang signifikan bagi upaya pengentasan kemiskinan dan pemerataan pembangunan agar pembangunan ekonomi dilaksanakan secara berkelanjutan dan inklusif.

Pada banyak kasus, sering kali keberlanjutan proses pertumbuhan ekonomi terhambat karena rendahnya modal sosial. Banyak faktor yang mempengaruhi tingkat akumulasi modal sosial yang rendah tersebut. Dalam kerangka diagnosa pertumbuhan, fenomena modal sosial yang rendah dapat disebabkan oleh rendahnya kapasitas modal manusia atau SDM atau karena rendahnya tingkat teknologi dan tidak memadainya kualitas infrastruktur.

Baik SDM, teknologi maupun infrastruktur merupakan faktor-faktor produksi yang diperlukan untuk mendukung pertumbuhan ekonomi yang berkelanjutan. Di samping kondisi SDM, teknologi dan infrastruktur, akumulasi modal sosial juga sangat tergantung pada kondisi geografis suatu negara. Indonesia yang merupakan negara kepulauan menghadapi masalah serius dalam membangun modal sosialnya.

Kondisi geografis jelas merupakan tantangan besar bagi Indonesia. Ditambah lagi dengan kondisi infrastruktur yang buruk, kondisi teknologi dan kapasitas SDM yang tidak memadai. Akibatnya, akumulasi modal sosial di ndonesia akan terhambat dan selanjutnya pertumbuhan akan terkendala. Pertumbuhan ekonomi yang berkelanjutan juga dapat terhambat karena adanya berbagai kegagalan pasar dan kegagalan pemerintah.

Kegagalan pemerintah bisa dalam bentuk kerentanan kondisi makro ekonomi, pajak yang tinggi, hak kepemilikan yang buruk, penegakkan hukum yang buruk, tata kelola yang, korupsi, dan kegagalan melakukan intermediasi dalam mengatasi konflik tenaga kerja dan pemilik modal. Sementara kegagalan pasar bisa dalam bentuk informasi yang tidak lengkap, timbulnya eksternalitas, dan kegagalan koordinasi.

Pertumbuhan ekonomi yang berkelanjutan memerlukan pendanaan yang murah dan kontinyu. Masalah pendanaan seringkali menjadi kendala utama bagi pembangunan ekonomi baik di Indonesia maupun di negara-negara berkembang lainnya. Kendala pendanaan dapat disebabkan karena rendahnya tingkat tabungan domestik, lemahnya sistem intermediasi di pasar keuangan domestik atau karena lemahnya integrasi pasar keuangan domestik dengan pasar keuangan global. Dalam kasus Indonesia, lemahnya sistem intermediasi keuangan domestik tampaknya menjadi kendala utama pertumbuhan ekonomi dalam jangka menengah dan jangka panjang. Sistem pendanaan investasi masih sangat didominasi oleh pendanaan dari sektor perbankan. Sedangkan sektor-sektor keuangan alternatif selain perbankan (pasar modal, obligasi, modal ventura, dan sebagainya) masih belum berkembang.

Terdapat tiga pilar kebijakan pembangunan ekonomi inklusif yang meliputi: (1) Pertumbuhan dan perkembangan ekonomi; (2) Pemerataan pendapatan dan pengurangan kemiskinan; (3) Perluasan akses dan kesempatan kerja.

Tantangan difabel dalam sektor ketenagakerjaan dan perekonomian, jika melihat dari ketiga pilar ini, memang terinternalisasi dari semua pilar.

\section{Pengeluaran Pemerintah}

Rudy Badrudin menjelaskan bahwa pengeluaran konsumsi pemerintah mencakup pengeluaran untuk belanja pegawai, penyusutan barang modal, dan belanja barang (termasuk belanja perjalanan, pemeliharaan, dan pengeluaran lain yang bersifat rutin) dikurangi penerimaan dari produksi barang dan jasa yang dihasilkan.

Pengeluaran konsumsi pemerintah tersebut meliputi pemerintah pusat dan pemerintah daerah. Pada dasarnya setiap pengeluaran negara dilakukan atas landasan prinsip optimalisasi pemanfaatan dana untuk mencapai sasaran-sasaran yang ditetapkan. Pengeluaran pemerintah harus mampu mencapai beberapa sasaran, seperti 
peningkatan produktivitas kerja aparatur pemerintah, perluasan jangkauan dan peningkatan kualitas pelayanan kepada masyarakat, pembinaan dan pengawasan pelaksanaan pembangunan serta terpeliharanya berbagai aset negara dan hasil-hasil pembangunan.

Pengeluaran pemerintah (Government Expenditure) adalah pengeluaran oleh pemerintah untuk membeli barang dan jasa. Sebagian dari pengeluaran pemerintah adalah untuk membiayai administrasi pemerintahan atau pengeluaran rutin dan sebagian lainnya untuk membiayai kegiatan-kegiatan pembangunan atau pengeluaran pembangunan. Pengeluaran rutin pemerintah terdiri dari belanja pegawai, belanja barang, belanja pemeliharaan, belanja perjalanan dinas, angsuran pinjaman/hutang dan bunga, ganjaran subsidi dan sumbangan pada daerah, pensiun dan bantuan, pengeluaran yang tidak termasuk bagian lain, dan pengeluaran tak terduga.

Pengeluaran pembangunan adalah pengeluaran yang ditujukan untuk membiayai proses perubahan, yang merupakan kemajuan dan perbaikan menuju kearah yang ingin dicapai. Umumnya biaya pembangunan tersebut diprogramkan dalam Daftar Isian Proyek (DIP). Pengeluaran pembangunan semuanya diprogramkan dalam berbagai proyek di setiap sektor dan sub sektor. Pengeluaran pembangunan tersebut dialokasikan ke berbagai sektor sesuai dengan urutan prioritas dan kebijakan pembangunan (Pakasi, 2005).

Pengeluaran pemerintah mencerminkan kebijakan pemerintah. Apabila pemerintah telah menetapkan suatu kebijakan untuk membeli barang dan jasa, pengeluaran pemerintah mencerminkan biaya yang harus dikeluarkan oleh pemerintah untuk melaksanakan kebijakan tersebut (Mangkoesoebroto, 1993; 169). Hubungan antara pengeluaran pemerintah dan pertumbuhan ekonomi secara teori diterangkan dalam Keynesian Cross (Mankiw, 2003; 263).

Bailey (1995; 43) membagi teori mengenai perkembangan pengeluaran pemerintah menjadi dua, yaitu teori makro dan teori mikro. Model makro dapat menjelaskan perhitungan jangka panjang pertumbuhan pengeluaran pemerintah, Bailey $(1995$; 43) membagi teori mengenai perkembangan pengeluaran pemerintah menjadi dua, yaitu teori makro dan teori mikro. Model makro dapat menjelaskan perhitungan jangka panjang pertumbuhan pengeluaran pemerintah,sedangkan model mikro menjelaskan perubahan secara particular komponenkomponen pengeluaran pemerintah. Teori makro mengenai perkembangan pengeluaran pemerintah dikelompokkan menjadi tiga golongan, yaitu (Mangkoesoebroto, 1993; 169):

1. Model pembangunan tentang perkembangan pengeluaran pemerintah.

2. Hukum Wagner mengenai perkembangan aktivitas pemerintah.

3. Teori Peacock \& Wiseman.

\section{Tingkat Pengangguran}

Definisi pengangguran dalam arti luas adalah penduduk yang tidak berkerja tetapi sedang mencari perkerjaan atau sedang mempersiapkan suatu usaha baru atau penduduk yang tidak mencari pekerjaan karena sudah diterima bekerja tetapi mulai bekerja.

Menurut Badan Pusat Statistik (BPS) dalam indikator ketenagakerjaan, pengangguran adalah penduduk yang tidak bekerja namun sedang mencari pekerjaan atau sedang mempersiapkan suatu usaha baru atau penduduk yang tidak mencari pekerjaan karena sudah diterima bekerja tetapi belum mulai bekerja.

Menurut Sukirno (1994), pengangguran adalah suatu keadaan dimana seseorang yang termasuk dalam angkatan kerja ingin memperoleh pekerjaan akan tetapi belum mendapatkannya. Seseorang yang tidak bekerja namun tidak secara aktif mencari pekerjaan tidak tergolong sebagai pengangguran. Fator utama yang menyebabkan terjadinya pengangguran adalah kurangnya pengeluaran agregat. Pengusaha memproduksi barang dan jasa dengan maksud memperoleh keuntungan, akan tetapi keuntungan tersebut akan diperoleh apabila pengusaha tersebut dapat menjual barang dan jasa yang mereka produksi. Semakin besar permintaan, semakin besar pula barang dan jasa yang mereka wujudkan. Kenaikan produksi yang dilakukan akan menambah penggunaan tenaga kerja.

Pengangguran merupakan masalah makroekonomi yang mempengaruhi kelangsungan hidup manusia secara langsung. Bagi kebanyakan orang kehilangan suatu pekerjaan merupakan penurunan suatu standar kehidupan. Jadi tidak mengejutkan apabila pengangguran menjadi topik yang sering diperbincangkan dalam perdebatan poltik oleh para politisi yang seringkali mengkaji bahwa kebijakan yang mereka tawarkan akan membantu terciptanya lapangan pekerjaan (Mankiw, 2000).

Untuk mengukur tingkat pengangguran suatu wilayah bisa diperoleh melalui dua pendekatan :

a. Pendekatan Angkatan Kerja (Labour force approach) Besar kecilnya tingkat pengangguran dapat dihitung berdasarkan presentase dan perbandingan jumlah antara orang yang menganggur dan jumlah angkatan kerja. 
Penganguran $=\frac{\text { Jumlah yang menganggur }}{\text { jumlah angkatan kerja }} \times 100 \%$

b. Pendekatan pemanfaatan tenaga kerja (Labour utilization approach)

- Bekerja penuh (employed) adalah orang-orang yang bekerja penuh atau jam kerjanya mencapai 35 jam per minggu.

- Setengah menganggur (underemployed) adalah mereka yang bekerja namun belum dimanfaatkan penuh atau jam kerjanya dalam seminggu kurang dari 35 jam.

\section{Teori - teori Pengangguran}

Ada beberapa teori yang menjelaskan tentang Toeri-Teori Pengangguran di Indonesia yaitu :

a. Teori Klasik

Teori Klasik menjelaskan pandangan bahwa pengangguran dapat dicegah melalui sisi penawaran dan mekanisme harga di pasar bebas supaya menjamin terciptanya permintaan yang akan menyerap semua penawaran. Menurut pandangan klasik, pengangguran terjadi karena mis-alokasi sumber daya yang bersifat sementara karena kemudian dapat diatasi dengan mekanisme harga (Gilarso. 2004).

Jadi dalam Teori Klasik jika terjadi kelebihan penawaran tenaga kerja maka upah akan turun dan hal tersebut mengakibatkan produksi perusahaan menjadi turun. Sehingga permintaan tenaga akan terus meningkat karena perusahaan mampu melakukan perluasan produksi akibat keuntungan yang diperoleh dari rendahnya biaya tadi. Peningkatan tenaga kerja selanjutnya mampu menyerap kelebihan tenaga kerja yang ada di pasar, apabila harga relatif stabil (Tohar. 2000).

b. Teori Keynes

Dalam menanggapi masalah pengangguran Teori Keynes mengatakan hal yang berlawanan dengan Teori Klasik, menurut Teori Keynes sesungguhnya masalah pengangguran terjadi akibat permintaan agregat yang rendah. Sehingga terhambatnya pertumbuhan ekonomi bukan disebabkan oleh rendahnya produksi akan tetapi rendahnya konsumsi. Menurut Keynes, hal ini tidak dapat dilimpahkan ke mekanisme pasar bebas. Ketika tenaga kerja meningkat, upah akan turun hal ini akan merugikan bukan menguntungkan, karena penurunan upah berarti menurunkan daya beli masyarakat terhadap barang-barang. Akhirnya produsen akan mengalami kerugian dan tidak dapat menyerap tenaga kerja.
Keynes menganjurkan adanya campur tangan pemerintah dalam mempertahankan tingkat permintaan agregat agar sektor pariwisata dapat menciptakan lapangan pekerjaan (Soesastro, dkk, 2005). Perlu dicermati bahwa pemerintah hanya bertugas untuk menjaga tingkat permintaan agregat, sementara penyedia lapangan kerja adalah sektor wisata. Hal ini memiliki tujuan mempertahankan pendapatan masyarakat agar daya beli masyarakat terjaga. Sehingga tidak memperparah resesi serta diharapkan mampu mengatasi pengangguran akibat resesi.

\section{Jenis-Jenis Pengangguran}

a. Pengangguran Berdasarkan Penyebabnya

Berdasarkan penyebabnya pengangguran dapat dibagi empat kelompok (Sukirno, 1994) :

1) Pengangguran Normal atau Friksional

Apabila dalam suatu ekonomi terdapat pengangguran sebanyak dua atau tiga persen dari jumlah tenaga kerja maka ekonomi itu sudah dipandang sebagai mencapai kesempatan kerja penuh. Pengangguran sebanyak dua atau tiga persen tersebut dinamakan pengangguran normal atau pengangguran friksional. Para penganggur ini tidak ada pekerjaan bukan karena tidak dapat memperoleh kerja, tetapi karena sedang mencari kerja lain yang lebih baik.

Dalam perekonomian yang berkembang pesat, pengangguran adalah rendah dan pekerjaan mudah diperoleh. Sebaliknya pengusaha susah memperoleh pekerja, akibatnya pengusaha menawarkan gaji yang lebih tinggi. Hal ini akan mendorong para pekerja untuk meninggalkan pekerjaanya yang lama dan mencari pekerjaan baru yang lebih tinggi gajinya atau lebih sesuai dengan keahliannya. Dalam proses mencari kerja baru ini untuk sementara para pekerja tersebut tergolong sebagai penganggur. Mereka inilah yang digolongkan sebagai pengangguran normal.

2) Penggangguran Siklikal

Perekonomian tidak selalu berkembang dengan teguh. Adakalanya permintaan agregat lebih tinggi, dan ini mendorong pengusaha menaikkan produksi. Lebih banyak pekerja baru digunakan dan pengangguran berkurang. Akan tetapi pada masa lainnya permintaan agregat menurun dengan banyaknya. Misalnya, di negara-negara produsen bahan mentah pertanian, penurunan ini mungkin disebabkan kemerosotan harga-harga komoditas. Kemunduran ini menimbulkan efek kepada perusahaan- 
perusahaan lain yang berhubungan, yang juga akan mengalami kemerosotan dalam permintaan terhadap produksinya. Kemerosotan permintaan agregat ini mengakibatkan perusahaanperusahaan mengurangi pekerja atau menutup perusahaanya, sehingga pengangguran akan bertambah. Pengangguran dengan wujud tersebut dinamakan pengangguran siklikal.

3) Pengangguran Struktural

Tidak semua industri dan perusahaan dalam perekonomian akan terus berkembang maju, sebagiannya akan mengalami kemunduran. Kemerosotan ini ditimbulkan oleh salah satu atau beberapa faktor berikut: wujudnya barang baru yang lebih baik, kemajuan teknologi mengurangi permintaan ke atas barang tersebut, biaya pengeluaran sudah sangat tinggi dan tidak mampu bersaing, dan ekspor produksi industri itu sangat menurun oleh karena persaingan yang lebih serius dari negara-negara lain. Kemerosotan itu akan menyebabkan kegiatan produksi dalam industri tersebut menurun, dan sebagian pekerja terpaksa diberhentikan dan menjadi penganggur. Pengangguran yang wujud digolongkan sebagai pengangguran struktural. Dinamakan demikian karena disebabkan oleh perubahan struktur kegiatan ekonomi.

4) Pengangguran Teknologi

Pengangguran dapat pula ditimbulkan oleh adanya penggantian tenaga manusia oleh mesinmesin dan bahan kimia. Racun ilalang dan rumput misalnya, telah mengurangi penggunaan tenaga kerja untuk membersihkan perkebunan, sawah dan lahan pertanian lain. Begitu juga mesin telah mengurangi kebutuhan tenaga kerja untuk membuat lubang, memotong rumput, membersihkan kawasan, dan memungut hasil. Sedangkan di pabrik- pabrik, ada kalanya robot telah menggantikan kerja-kerja manusia. Pengangguran yang ditimbulkan oleh penggunaan mesin dan kemajuan teknologi lainnya dinamakan pengangguran teknologi.

b. Penggangguran Berdasarkan Cirinya

Berdasarkan cirinya, Pengangguran dibagi menjadi empat kelompok (Sukirno, 1994):

1. Pengangguran Terbuka

Pengangguran ini tercipta sebagai akibat pertambahan lowongan pekerjaan yang lebih rendah dari pertambahan tenaga kerja. Sebagai akibatnya dalam perekonomian semakin banyak jumlah tenaga kerja yang tidak dapat memperoleh pekerjaan. Efek dari keadaan ini di dalam suatu jangka masa yang cukup panjang mereka tidak melakukan suatu pekerjaan. Jadi mereka menganggur secara nyata dan separuh waktu, dan oleh karenanya dinamakan pengangguran terbuka. Pengangguran terbuka dapat pula wujud sebagai akibat dari kegiatan ekonomi yang menurun, dari kemajuan teknologi yang mengurangi penggunaan tenaga kerja, atau sebagai akibat dari kemunduran perkembangan suatu industri.

2. Pengangguran Tersembunyi

Pengangguran ini terutama wujud di sektor pertanian atau jasa. Setiap kegiatan ekonomi memerlukan tenaga kerja, dan jumlah tenaga kerja yang digunakan tergantung pada banyak faktor, factor yang perlu dipertimbangkan adalah besar kecilnya perusahaan, jenis kegiatan perusahaan, mesin yang digunakan (apakah intensif buruh atau intensif modal) dan tingkat produksi yang dicapai. Pada negara berkembang seringkali didapati bahwa jumlah pekerja dalam suatu kegiatan ekonomi adalah lebih banyak dari yang sebenarnya diperlukan supaya ia dapat menjalankan kegiatannya dengan efisien. Kelebihan tenaga kerja yang digunakan digolongkan dalam pengangguran tersembunyi. Contoh-contohnya ialah pelayan restoran yang lebih banyak dari yang diperlukan dan keluarga petani dengan anggota keluarga yang besar yang mengerjakan luas tanah yang sangat kecil.

3. Pengangguran Musiman

Pengangguran ini terutama terdapat di sektor pertanian dan perikanan. Pada musim hujan penyadap karet dan nelayan tidak dapat melakukan pekerjaan mereka dan terpaksa menganggur. Pada musim kemarau pula para petani tidak dapat mengerjakan tanahnya. Disamping itu pada umumnya para petani tidak begitu aktif di antara waktu sesudah menanam dan sesudah menuai. Apabila dalam masa tersebut para penyadap karet, nelayan dan petani tidak melakukan pekerjaan lain maka mereka terpaksa menganggur. Pengangguran seperti ini digolongkan sebagai pengangguran bermusim.

4. Setengah Menganggur

Pada negara-negara berkembang migrasi dari desa ke kota sangat pesat. Sebagai akibatnya tidak semua orang yang pindah ke kota dapat memperoleh pekerjaan dengan mudah. Sebagian terpaksa menjadi penganggur sepenuh waktu. Disamping itu ada pula yang tidak menganggur, 
tetapi tidak pula bekerja sepenuh waktu, dan jam kerja mereka adalah jauh lebih rendah dari yang normal. Mereka mungkin hanya bekerja satu hingga dua hari seminggu, atau satu hingga empat jam sehari. Pekerja-pekerja yang mempunyai masa kerja seperti yang dijelaskan ini digolongkan sebagai setengah menganggur (underemployed). Dan jenis penganggurannya dinamakan underemployment.

\section{Metodologi Penelitian}

Jenis penelitian yang digunakan pada penelitian ini adalah penelitian kuantitatif deskriptif.

Jenis data yang digunakan dalam penelitian ini yaitu data sekunder, dimana data yang diperoleh bersumber dari Publikasi Badan Pusat Statistik (BPS).

Dengan menggunakan variabel dependen (terikat) yaitu Pertumbuhan Ekonomi Inklusif Indoensia tahun 2010-2019, sedangkan untuk variabel independent (bebas) menggunakan data Pengeluaran Pemerintah Bidang Pendidikan Indonesia tahun 2010-2019, Pengeluaran Pemerintah Bidang Kesehatan Indonesia tahun 2010-2019 dan Tingkat Pengganguran Terbuka (TPT) Indonesia tahun 2010-2019. Data yang digunakan dalam penelitian ini yaitu data pada level nasional.

Teknik pengumpulan data yang dilakukan oleh peneliti adalah menggunakan teknik dokumentasi. Pada penelitian ini digunakan dua metode analisis data, sebagai berikut:

\section{Spesifikasi Model Poverty-Equivalent Growth Rate (PEGR)}

Analisis deskriptif yang digunakan oleh peneliti untuk menganalisis kondisi pertumbuhan ekonomi inklusif di Indonesia. Pengukuran pertumbuhan ekonomi inklusif dengan konsep PEGR meliputi tiga dimensi pengukuran. Perhitungan dengan metode PEGR merupakan metode yang relevan untuk digunakan menghitung koefisien pertumbuhan ekonomi inklusif dengan membandingkan data keadaan kemiskinan, distribusi pendapatan, dan rata-rata penduduk. Penelitian ini pengukuran pertumbuhan ekonomi inklusif dalam mengurangi kemiskinan. Dengan menggunakan analisis deskriptif akan dilihat tingkat pertumbuhan ekonomi inklusif di Indonesia setiap tahunnya.
Dengan menggunakan konsep Klassen dalam penelitian ini, indikator pertumbuan inklusif dalam penurunan kemiskinan sebagai $(i)$, sebagai kemiskinan $(p)$ dan yang mengacu pada indikator pertumbuhan ekonomi ( $g$ ), maka model analisis terkait fenomena inklusifitas pertumbuhan yang digunakan adalah sebagai berikut:

$\mathrm{IGp}=(\mathrm{Gpg} / \mathrm{Gp}) \hat{\mathrm{G} g}$

Di mana:

IGp : koefisien pertumbuhan inklusif dalam menurunkan kemiskinan

$\mathrm{Gp}$ : elastisitas kemiskinan terhadap pendapatan rata-rata

Gpg : elastisitas kemiskinan terhadap pertumbuhan ekonomi

$\hat{\mathrm{Gg}}$ : pertumbuhan ekonomi

Igp : menyatakan inklusifitas pertumbuhan dalam menurunkan kemiskinan, sehingga pertumbuhan dinyatakan inklusif apabila nilai IGp $>$ Ĝg.

Nilai Gpg dan Gp pada persamaan 1 di atas diperoleh dengan cara yang sama dalam konsep PEGR.

Dengan mendefinisikan kemiskinan (P) sebagai fungsi dari jumlah penduduk miskin $(\mathrm{z})$ dan pendapatan rata-rata penduduk $(\mathrm{x})$ yang dirumuskan sebagai berikut:

$\mathrm{P}=\mathrm{P}(\mathrm{z}, \mathrm{x})$

Maka perubahan persentase jumlah penduduk miskin pada periode 1 dan periode 2 dapat dituliskan sebagai berikut ini:

$\mathrm{P} 12=\mathrm{P} 2-\mathrm{P} 1=\operatorname{Ln}[\mathrm{P}(\mathrm{z} 2, \mathrm{x} 2)]-\operatorname{Ln}[\mathrm{P}(\mathrm{z} 1, \mathrm{x} 1)]$

Dan perubahan persentase pendapatan rata-rata penduduk dapat dihitung sebagai:

$\Psi=\operatorname{Ln}(\mathrm{x} 2)-\operatorname{Ln}(\mathrm{x} 1)$.

Dengan demikian elastisitas kemiskinan terhadap pendapatan rata-rata $(\mathrm{Gp})$ dapat dihitung sebagai:

$\mathrm{Gp}=\mathrm{P} 12 / \Psi$

Sementara perubahan pertumbuhan ekonomi ( $\hat{\mathrm{Gg}}$ ) yang dihitung dari Produk Domestik Bruto (PDB), sehingga perubahan pertumbuhan ekonomi periode 1 dan periode 2 dapat dituliskan sebagai:

$\hat{\mathrm{G} g}=\operatorname{Ln}(\mathrm{PDRB} 2)-\mathrm{Ln}(\mathrm{PDRB} 1)$

(6)

Dengan demikian, elastisias kemiskinan terhadap pertumbuhan ekonomi (Gpg) dapat dihitung sebagai :

$\mathrm{Gpg}=\mathrm{P} 12 / \hat{\mathrm{G} g}$

Hasil yang diperoleh dari perhitungan persamaan (5) dan (7) diatas kemudian dimasukkan ke dalam persamaan (1) untuk memperoleh nilai indeks pertumbuhan inklusif yang kemudian digunakan untuk dibandingkan dengan nilai pertumbuhan ekonomi (Ĝg). 


\section{Spesifikasi Model Regresi}

Metode analisis yang digunakan didalam penelitian ini adalah regresi linier berganda dengan jenis penelitian yang menggunakan deret waktu dan dengan lokasi penelitian di satu tempat.

Berikut merupakan model analisis regresi dengan data time series yang digunakan dalam penelitian ini adalah :

$\mathrm{Y}=\beta 0+\beta \operatorname{LnXt} 1+\beta \operatorname{LnXt} 2+\beta \operatorname{LnXt} 3+\ldots . .+\mathrm{e}$

Keterangan :

$\mathrm{Y}=$ Indeks Pertumbuhan Ekonomi Inklusif (\%)
$\beta 0=$ Konstanta
$\beta \mathrm{n} \quad=$ Koefisien Regresi
Ln = Logaritma Natural
Xt1 = Belanja Pendidikan (miliar Rp)
$\mathrm{Xt2}=$ Belanja Kesehatan (miliar Rp)
Xt3 = Tingkat Pengganguran Terbuka $(\%)$
$\mathrm{T}=$ Time Series Tahun 2010-2019

\section{Hasil Dan Pembahasan}

Hasil Analisis Model Poverty-Equivalent Growth Rate (PEGR)

Tabel1.

Analisis Model PEGR

\begin{tabular}{|c|c|c|c|}
\hline Tahun & Gg & IGp & Hasil \\
\hline 2010 & -0.33 & -0.32 & Tidak inklusif \\
\hline 2011 & -0.16 & -0.15 & Tidak inklusif \\
\hline 2012 & -0.02 & -0.01 & Tidak inklusif \\
\hline 2013 & 0.005 & 0.019 & inklusif \\
\hline 2014 & 0.02 & 0.03 & inklusif \\
\hline 2015 & 0.03 & 0.04 & inklusif \\
\hline 2016 & -0.07 & -0.06 & Tidak inklusif \\
\hline 2017 & -0.08 & -0.07 & Tidak inklusif \\
\hline 2018 & -0.02 & -0.01 & Tidak inklusif \\
\hline 2019 & -0.07 & -0.06 & Tidak inklusif \\
\hline
\end{tabular}

Sumber: Data diolah (2020)

Tabel 1 menunjukkan bahwa pada beberapa periode penelitian, nilai koefisien pertumbuhan inklusif di Indonesia tidak pernah konsisten mencapai pertumbuhan yang inklusif, pada tahun 2010-2012 kondisi pertumbuhan ekonomi dalam mengurangi kemiskinan tidak inklusif, berbeda dengan tahun 2013-2015 kondisi pertumbuhan ekonomi dalam mengurangi kemiskinan di Indonesia dapat inklusif. Namun pada tahun selanjutnya 2016-2019 dengan Pertumbuhan Ekonomi yang terus mengalami kenaikan tetapi Pertumbuhan tersebut tidak inklusif dalam mengurangi kemiskinan. Dari hasil tersebut pada tahun 2011 dan tahun 2012 pertumbuhan ekonomi menunjukkan angka peningkatan namun dalam tabel menunjukkan pertumbuhan ekonomi tersebut tidak inklusif dalam menurunkan kemiskinan, begitu pula pada tahun 2016 hingga tahun 2019 menunjukkan peningkatan meskipun tahun 2018 sedikit mengalami penurunan, namun inklusifitas pertumbuhan ekonomi belum dapat tercapai pada tahun-tahun tersebut. Oleh karena itu, untuk mewujudkan Pertumbuhan Ekonomi ke arah Pro-Poor, maka terdapat faktor-faktor yang dapat mempengaruhi Pertumbuhan Ekonomi Inklusif di Indonesia khususnya dalam mengurangi kemiskinan. 


\begin{tabular}{c|ccccllr}
\multicolumn{8}{c}{ Hasil Analisis Statistik Regresi Data Time Series } \\
Source & SS & df & MS & & Number of obs & $=$ & \\
& & & F $(3,6)$ & $=$ & \\
Model & .08487791 & 3 & .028292637 & & Prob $>$ F & $=$ & 0.90 \\
Residual & .024586771 & 6 & .004097795 & & R - squared & $=$ & 0.7754 \\
& & & & & Adj R - squard & $=$ & 0.6631 \\
Total & .109464681 & 9 & .012162742 & & Root MSE & $=$ & .06401
\end{tabular}

\begin{tabular}{r|rrrrrr}
\hline igp & Coef. & Std.Err & $\mathrm{t}$ & $\mathrm{p}>|\mathrm{t}|$ & (95\% Conf. & Interval) \\
\hline ln_pend & 1.040116 & .2823109 & 3.68 & 0.010 & .3493265 & 1.730906 \\
ln_kas & -.4528105 & .1532369 & -2.95 & 0.025 & -.8277676 & -.0778534 \\
ln_tpt & -.215043 & .2768042 & -0.78 & 0.467 & -.8923584 & .4622723 \\
_cons & -7.944031 & 2.708159 & -2.93 & 0.026 & -14.57066 & -1.317406 \\
\hline
\end{tabular}

Sumber: Data diolah (2020)

Berdasarkan hasil perhitungan regresi menunjukkan bahhwatime series, dengan hasil uji koefisien determinasi (R2) bahwa masing-masing variabel pengeluaran pemerintah bidang pendidikan, pengeluaran pemerintah bidang kesehatan, dan tingkat pengangguran terbuka dalam menjelaskan variabel terikat yaitu pertumbuhan ekonomi inklusif sebesar 77.54\%. Dan sisanya sebesar $22.46 \%$ dijelaskan oleh variabel lain diluar model. Dari hasil uji parsial menunjukkan bahwa variabel pengeluaran pemerintah bidang pendidikan berpengaruh signifikan terhadap pertumbuhan ekonomi inklusif namun memiliki koefisien pertumbuhan ekonomi inklusif negatif. Variabel pengeluaran pemerintah bidang kesehatan berpengaruh signifikan terhadap pertumbuhan ekonomi inklusif. Variabel tingkat pengangguran terbuka (TPT) berpengaruh tidak signifikan terhadap pertumbuhan ekonomi inklusif.

Dari tiga variabel bebas dan satu variabel terikat yang digunakan dalam penelitian ini maka diperoleh model sebagai berikut :

\section{IPEI = -7.944031+1.040116 Belanja Pendidikan - 0.4528105 Belanja Kesehatan - 0.215043 TPT + e}

Dari hasil pengolahan data, variabel pengeluaran pemerintah bidang pendidikan memiliki pengaruh signifikan terhadap pertumbuhan ekonomi inklusif. Dengan nilai probabilitas $0.010<0.05$. Yang artinya ketika belanja pendidikan menurun 1 miliar $\mathrm{Rp}$, maka pertumbuhan ekonomi inklusif akan meningkat 1.040116 sebesar persen secara rata-rata, dengan asumsi variabel lain tidak berubah. Menurut teori, pengeluaran pemerintah termasuk suatu kebijakan pemerintah, yaitu kebijakan fiskal, yang bertujuan untuk mengontrol stabilitas ekonomi maupun sosial melalui distribusi pendapatan. Pengeluaran pemerintah pada bidang pendidikan merupakan suatu bentuk kebijakan yaitu investasi terhadap sumber daya manusia. Melalui pengeluaran pemerintah khususnya bidang pendidikan, pemerintah dapat mengambil kebijakan melalui secara umum perbaikan sistem pendidikan yang lebih modern, mengadakan pembangunan sarana dan prasarana pendidikan. Dengan hal tersebut kemajuan teknologi sangat perlu selaras dengan adanya perbaikan peningkatan kualitas sumber daya manusia. Secara luas ketika teknologi dapat disebarkan di seluruh wilayah di Indonesia maka juga akan meningkatkan kemampuan dari transfer ilmu pengetahuan antar wilayah yang mereka tidak bisa dapatkan di daerah mereka serta kreatifitas masyarakat, hal ini tidak hanya dapat mendorong output secara agregat namun juga akan dapat mendorong terbukanya lapangan pekerjaan secara merata.

Variabel pengeluaran pemerintah bidang kesehatan memiliki pengaruh signifikan terhadap pertumbuhan ekonomi inklusif. Dengan nilai probabilitas $0.025<0.05$. Artinya ketika belanja kesehatan menurun sebesar 1 miliar $\mathrm{Rp}$, maka pertumbuhan ekonomi inklusif akan menurun sebesar 0.4528105 persen secara rata-rata, dengan asumsi variabel lain tidak berubah. Begitupun sebaliknya apabila belanja kesehatan meningkat maka pertumbuhan ekonomi inklusif akan meningkat.

Hal ini sesuai dengan teori Wagner, pengeluaran pemerintah akan meningkat karena adanya interaksi dalam masyarakat yang salah satu nya yaitu pada perbaikan tingkat kesehatan. Pengeluaran pemerintah bidang kesehatan juga termasuk dalam investasi modal manusia, karena kebutuhan mendasar manusia adalah kesehatan, sehingga pembangunan kesehatan melalui pengeluaran pemerintah juga merupakan suatu kebijakan yang terus ditingkatkan oleh pemerintah. Sehingga meningkatnya produktivitas juga terjadi karena dari peningkatan pada 
tingkat kesehatan masyarakat. Hal tersebut yang dapat mendorong pertumbuhan ekonomi yang dibarengi dengan peningkatan pembangunan sumber daya manusia sehingga masyarakat dapat berupaya menyesuaikan dalam pasar tenaga kerja sehingga dapat mengarah pada percepatan pencapaian pertumbuhan ekonomi inklusif.

Variabel tingkat pengangguran terbuka (TPT) memiliki pengaruh tidak signifikan terhadap pertumbuhan ekonomi inklusif. Dengan nilai probabilitas 0.467>0.05. Artinya, ketika Tingkat Pengangguan Terbuka menurun sebesar 1 persen maka pertumbuhan ekonomi inklusif akan menurun sebesar 0.215043 persen secara rata-rata, dengan asumsi variabel lain tetap. Berdasarkan data pada Badan Pusat Statistik menunjukkan dalam satu dekade terakhir persentase tingkat partisipasi angkatan kerja (TPAK) cenderung menurun di beberapa tahun pada. Hal ini dapat disebabkan karena adanya faktor internal tenaga kerja ataupun factor eksternal tenaga kerja. Faktor eksternal tersebut dapat terjadi karena adanya pergeseran penyerapan tenaga kerja pada berbagai sektor atau lapangan usaha. Pendapatan masyarakat antar sektor usaha dapat bergeser, ketika jumlah pengangguran satu sektor di Indonesia mengalami peningkatan dan disamping itu terdapat penurunan jumlah pengangguran pada sektor lain.

Menurut Badan Pusat Statistik, pada tahun 2018 ke tahun 2019 lapangan pekerjaan utama di Indonesia yang meningkat yaitu Penyediaan Akomodasi dan Makan Minum (0,05 persen), Industri Pengolahan (0,024 persen), dan Perdagangan (0,20 persen). Sementara itu pada tahun 2016 ke tahun 2017 lapangan pekerja utama yang meningkat diantaranya sektor Industri ( 0,93 persen), sektor Perdagangan (0,74 persen), dan sektor Jasa Kemasyarakatan (0,49 persen). Pada tahun 2014 ke tahun 2015 peningkatan lapangan pekerjaan utama ada pada sektor Kontruksi (12,77\%), sektor Perdagangan (3,42\%) dan sektor Keuangan (7,92\%). Pada tahun 2012 ke tahun 2013 peningkatan lapangan lapangan pekerjaan utama ada pada sektor Jasa Kemasyarakatan (6,49\%), sektor Perdagangan (2,50\%), dan sektor Keuangan (9,40\%). Selanjutnya, pada tahun 2010 ke 2011 peningkatan lapangan pekerjaan utama terjadi pada sektor 1 yaitu Pertanian, Perburuan, Perikanan menyerap tenaga kerja hingga $(35,86 \%)$.

\section{Kesimpulan}

Berdasarkan hasil penelitian yang diperoleh, bahwa pertumbuhan ekonomi dalam mencapai inklusifitas terwujud pada tahun 2013-2015 dalam satu dekade terakhir dan tidak konsisten dalam 10 tahun terakhir. Hasil dari analisis regresi linier berganda data time series yaitu variabel pengeluaran pemerintah bidang pendidikan memiliki pengaruh yang signifikan terhadap pertumbuhan ekonomi inklusif, adapun kebijakan di bidang pendidikan oleh pemerintah selama periode pengamatan seperti perbaikan sistem pendidikan yang lebih modern, pembangunan sarana dan prasarana sekolah, dll, namun pengaruh dari hasil berbanding terbalik. Variabel pengeluaran pemerintah bidang kesehehatan memiliki pengaruh yang signifikan terhadap pertumbuhan ekonomi inklusif. Variabel tingkat pengangguran terbuka memiliki pengaruh yang tidak signifikan terhadap pertumbuhan ekonomi inklusif. Sehingga variabel pengeluaran pemerintah bidang pendidikan dan bidang kesehatan merupakan faktor pendukung tercapainya pertumbuhan ekonomi inklusif di Indonesia, namun melalui pengeluaran pemerintah bidang pendidikan belum maksimal hasil yang dicapai.

Berdasarkan hasil penelitian yang diperoleh, maka saran untuk penelitian selanjutnya diharapkan menggunakan metode yang berbeda dan menambahkan variabel di luar model yang dapat mempengaruhi secara signifikan percepatan pertumbuhan ekonomi inklusif di Indonesia.

Berdasarkan hasil penelitian menujukkan beberapa hal yang dapat menunjang mempercepat pertumbuhan ekonomi inklusif melalui implikasi kebijakan pemerintah, diantaranya melalui pengeluaran pemerintah bidang pendidikan terdapat penguatan kebijakan seperti meningkatkan pemberian insentif melalui Program Indonesia Pintar (PIP) yaitu Kartu Indonesia Pintar, beasiswa bagi masyarakat dengan kondisi ekonomi menengah kebawah secara merata hingga diadakan penguatan pendidikan vokasi yang baru saja ditegakkan. Dan disisi lain, pada program kesehatan melalui peningkatan penambahan sarana prasarana, jumlah tenaga medis hingga program Kartu Indonesia Sehat juga pada BPJS kesehatan. Juga melakukan pelatihan-pelatihan keterampilan terhadap tenaga kerja. Maka dengan adanya kebijakan tersebut merupakan beberapa upaya bagi pembangunan sumber daya manusia, dengan adanya perbaikan pada pembangunan sumber daya manusia akan mengarah pada produktivitas, terjadinya kesesuaian antara supply tenaga kerja terhadap permintaan tenaga kerja hingga peningkatan output secara agregat dan tercapainya pertumbuhan ekonomi yang lebih inklusif.

\section{Daftar Pustaka}

Amalina, D. H., Hutagaol, M. P., \& Asmara, A. (2013). Pertumbuhan Ekonomi Inklusif Di Kawasan Indonesia Bagian Barat Dan Indonesia Bagian Timur. Jurnal Ekonomi Dan Kebijakan Pembangunan, 2(2), 85-112. 
Azwar. (2016). Pertumbuhan Inklusif Di Provinsi Sulawesi Selatan Dan Faktor-Faktor Yang Mempengaruhinya. Badan Pendidikan Dan Pelatihan Keuangan Kementrian Keuangan Republik Indonesia, 9(2), 1-31.

Bastias, D. D. (2010). Analisis Pengaruh Pengeluaran Pemerintah Atas Pendidikan, Kesehatan Dan Infrastruktur Terhadap Pertumbuhan Ekonomi Indonesia Periode 1969-2009. Semarang: Fakultas Ekonomi Universitas Diponegoro.

Badan Pusat Statistik. 2019. Jumlah Penduduk Miskin Indonesia Tahun 2009-2010. Jakarta.

Badan Pusat Statistik, B. (n.d.-a). Indeks Gini Indonesia. https://www.bps.go.id/statictable/2014/09/08/946/distribusi -pembagian-pengeluaran-per-kapita-dan-indeksgini-2010-2019.html

Badan Pusat Statistik, B. (n.d.-b). Tingkat Pengangguran Terbuka (TPT) Indonesia. https://www.bps.go.id/dynamictable/2020/02/19/1 774/tingkat-pengangguran-terbuka-tpt-menurutprovinsi-1986---2019.html

Dianaputra, I. G. K. A., \& Aswitari, L. P. (2017). Pengaruh Pembiayaan Pemerintah Di Sektor Pendidikan Dan Kesehatan Terhadap Indeks Kualitas Manusia Serta Pertumbuhan Ekonomi Pada Kabupaten/Kota Provinsi Bali Tahun 2011-2015. E-Jurnal Ekonomi Pembangunan, 6(3), 286-311.

Fathurahman, M., \& Haeruddin. (2011). Pemodelan Regresi Linier untuk Data Deret Waktu Linear Regression Modeling for Time Series Data. Eksponensial, 2(ISSN 2085-7829), 35-42.

Fitrianda, M. I. (2013). Pengaruh Jumlah Penduduk, Tingkat Partisipasi Angkatan Kerja (TPAK), Pengganguran Dan Kemiskinan Terhadap Pertumbuhan Ekonomi Provinsi Jawa Timur Tahun 1988-2018. Digital Repository Universitas Jember.

Ghozali, I., \& Ratmono, D. (2013). Analisis Multivariat Dan Ekonometrika. Universitas Diponegoro Semarang.

Habito, C. F. (2009). Patterns of Inclusive Growth in Developing Asia: Insights from an Enhanced Growth-Poverty Elasticity Analysis (ADBI Working Paper Series). Asian Development Bank Institute. http://www.adbi.org/workingpaper/2009/08/12/3265.patterns.inclusive.growth. dev.asia/

Hidayah, Z. M. (2020). Pengaruh Indikator Pembangunan Ekonomi Terhadap Pertumbuhan Ekonomi Di Provinsi Jawa Timur. Purwanti, S.D., Rahmawati, $F$.
Klasen, S. (2010). Measuring and Monitoring Inclusive Growth : Multiple Definitions, Open Questions, and Some Constructive Proposals. $A D B$ Sustainable Development Working Paper Series, Asian Development Bank, 12.

Maipita, I., Jantan, M. D., \& Razak, N. A. A. (2010). Dampak Kebijaka Fiskal Terhadap Kinerja Ekonomi Dan Angka Kemiskinan Di Indonesia. Buletin Ekonomi Moneter dan Perbankan, 12(4), 421-456.

Martono, N. (2010). Metode Penelitian Kuantitatif. Jakarta: PT Rajagrafindo Persada.

Meyer, D., \& Meyer, N. (2019). Assessment of Inclusive Growth performance: A comparative analysis of the BRICS countries. Acta Universitatis Danubius. OEconomica, 15(4), 191-207.

Mutijo, Kusriatmi, Suryono, Waluyo, Oktavia, G., Pafrida, M., Astuti, F. P., \& Nurita. (2016). Analisis Pertumbuhan Ekonomi Inklusif Daerah Istimewa Yogyakarta 2011-2015. Laporan Akhir. Bappeda DI Yogyakarta.

Prabandari, D. A. N., \& Santoso, D. B. (2018). Analisis Inklusivitas Pertumbuhan Ekonomi Di Jawa Timur Dan Faktor-Faktor Yang Mempengaruhinya. Jurnal Ilmiah Mahasiwa FEB Universitas Brawijaya, 7 (2), 1-12.

Prasetyo, T. H., \& Sulistyaningrum, E. (2013). Pengaruh Belanja Pemerintah Terhadap Pertumbuhan Ekonomi Studi Kasus: Provinsi Sulawesi Barat, 2006-2013.

Raheem, I. D., Isah, K. O., \& Adedeji, A. A. (2018). Inclusive growth, human capital development and natural resource rent in SSA. Economic Change and Restructuring, 51(1), 29-48. https://doi.org/10.1007/s10644-016-9193-y

Safira, Djohan, S., \& Nurjanana. (2019). Pengaruh Pengeluaran Pemerintah Pada Bidang Infrastruktur Pendidikan Dan Kesehatan Terhadap Pertumbuhan Ekonomi Di Provinsi Kalimantan Timur. Jurnal Ekonomi Manajemen Akuntansi Forum Ekonomi, 21(2), 211-216.

Sholihah, D. H. A. (2014). Pertumbuhan inklusif : faktorfaktor yang memengaruhi dan dampaknya terhadap pertumbuhan kelas menengah di Indonesia [Institut Pertanian Bogor]. https://repository.ipb.ac.id/handle/123456789/746 97

Sheraphim, G. K. (2018). Pengaruh Tingkat Inklusi Keuangan, Tingkat Pengganguran Terbuka (TPT), Dana Pihak Ketiga (DPK), Dan Penanaman Modal Dalam Negeri (PMDN) Terhadap Tingkat 
Pertumbuhan Ekonomi Di 33 Provinsi Indonesia Periode 2011-2016. Jurnal Ilmiah Mahasiwa FEB Universitas Brawijaya, 1-22.

Sugianto, \& Permadhy, Y. T. (2020). Perencanaan Pembangunan Inklusif Melalui Peran Partisipatif Pemerintah Daerah. EcceS : Economics Social and Development Studies Abstract : Inclusive Development Planning Through The. 7(1), 87-109. https://doi.org/10.24252/ecc.v7i1.13565

Sukirno, S. (2011). Ekonomi Pembangunan (Agus (ed.); Kedua). Jakarta: Kencana Prenada Media Group.

Suparno, H. (2014). Pengaruh Pengeluaran Pemerintah Sektor Pendidikan, Kesehatan, Dan Infrastruktur Terhadap Pertumbuhan Ekonomi Dan Peningkatan Pembangunan Manusia Di Provinsi Kalimantan Timur. Journal of Innovation in Business \& Economics, 5(1), 1-22.

Tambunan, T. (2016). Pembangunan Ekonomi Inklusif (Pertama). Jakarta: LP3ES.

Todaro, M. P., \& Smith, S. C. (2006). Ekonomi Pembangunan (D. Barnadi, S. Suraydi, \& H. Wibi (eds.); sembilan). Jakarta: Erlangga.://eprints.undip.ac.id/44748 